Review Article

\title{
Potential for Recycling Nutrients from Biosolids Amended with Clay and Lime in Coarse-Textured Water Repellence, Acidic Soils of Western Australia
}

\author{
Sanjutha Shanmugam and Lynette K. Abbott \\ Soil Biology and Molecular Ecology Group, School of Earth and Environment and UWA Institute of Agriculture, \\ Faculty of Science, The University of Western Australia, 35 Stirling Highway, M087, Crawley, WA 6009, Australia
}

Correspondence should be addressed to Sanjutha Shanmugam; sanjutha.shanmugam@gmail.com

Received 27 September 2014; Accepted 29 December 2014

Academic Editor: Silvana Irene Torri

Copyright (c) 2015 S. Shanmugam and L. K. Abbott. This is an open access article distributed under the Creative Commons Attribution License, which permits unrestricted use, distribution, and reproduction in any medium, provided the original work is properly cited.

Application of biosolids in soils is an efficient method of recycling nutrients from biosolids and it is considered even safer when it is modified after mixing and diluting with other suitable soil organic amendments. A variety of soil organic amendments, such as green manures and composts, are used for modifying and co-composting with biosolids. However, these may not be considered as appropriate biosolids disposal and remedial measures for soils with unique problems such as low soil $\mathrm{pH}$, water repellence nature, and poor water and nutrient retention capacities due to soil textural issues. Historically, soil amendments such as lime, clay, and recently biochar are being applied for such problematic soils at Western Australia and these researches focused mostly on improvement in soil physical and chemical properties. However, studies with potential for applying modified biosolids with these amendments are not complete yet. This review focused on identifying such gaps in these studies from over 170 peer-reviewed key research and review articles published over decades to latest in these areas.

\section{Introduction}

Coarse-textured, sandy soils are common in Mediterranean regions of Australia, which extend from Geraldton north of Perth, across south-western Australia and southern-south Australia, and into the Wimmera, Mallee, and northern districts of Victoria [1]. The Swan Coastal Plain on the coast of south-western Australia, within this Mediterranean environment, experiences hot dry summer and cool, wet winter with annual rainfall ranges between 500 and $600 \mathrm{~mm}$ [2]. Low fertility and soil nutrient deficiency are common in this climatic zone as the soils are derived from weathered, ancient rocks and are low in soil organic matter $[1,3]$. Deep sand occurs at more than $80 \mathrm{~cm}$ depth and the pale deep sand found on the Swan Coastal Plain is typically classified as bleached-Orthic Tenosol [4]. Soil acidity, water repellence, poor water-holding, nutrient leaching, and environmental degradation are major issues that need improved soil management practices to increase productivity in the dry-land farming zones of this region $[1,5,6]$.

Biosolids disposal is an international environmental issue as many developed countries are incinerating their biosolids or disposing them as landfills and ocean dumps [7]. Global production of biosolids exceeds $10 \mathrm{Mt} \mathrm{yr}^{-1}$ and the production average is $27 \mathrm{~kg}$ of dry biosolids person ${ }^{-1}$ year $^{-1}$ [8]. Several studies have focused on the advantage of recycling biosolids for beneficial agronomic effects on soil fertility from the organic matter and readily available and/or slow release plant nutrients available in the sludge [9-12]. Sludge addition usually increased plant growth both in field and in greenhouse experiments on different crop species [13-15]. On the contrary, research on the limitations of biosolids has demonstrated that excessively applied biosolids can release 
heavy metal and the metal accumulation and cause stress and restrictive effects on soil microbes [16-24] and on plant root and shoot biomass [25].

Other studies have focused on managing excessive $\mathrm{N}$ and $\mathrm{P}$ nutrient release from biosolids and risk for nearby surface water quality [26-29]. For instance, the Western Australian State of the Environment Report identified that eutrophication led to nearly $30 \%$ of accidental fish kills associated with excessive $\mathrm{P}$ and $\mathrm{N}$ leaching into waterways through fertiliser application $\left(\mathrm{TN}=0.75 \mathrm{mg} \mathrm{N} \mathrm{L}^{-1}, \mathrm{TP}=0.03 \mathrm{mg} \mathrm{P} \mathrm{L}^{-1}\right.$ trigger values indicated for the Swan-Canning estuaries as per guidelines of ANZECC and ARMCANZ) [30]. These studies show that no generalised application rate can be recommended; rather it is necessary to investigate sources of biosolids separately for a particular soil due to varying content of nutrients and metals present within biosolids [31-35].

1.1. Modified Biosolids Products. Traditionally, biosolids are applied to land in their original form for their nutritional value after treating raw sludge $[15,36,37]$. Plant nutrient imbalances as either deficiencies or phytotoxicities can occur when using these materials in unmodified forms [38]. This could outweigh the fertiliser value of sludge application. However, it is possible to rectify this problem by slightly modifying the physical and chemical properties of biosolids in addition to improving their formulation for safe disposal for specific soil conditions [38].

Several forms of modified biosolids are available for use in agriculture. The simple form of a biosolids mixture is lime-stabilised biosolids or LAB (lime-amended biosolids) $[39,40]$. For example, a study conducted by Sloan and Basta [9] noticed that alkaline biosolids caused greater reductions in phytotoxic-Al when applied in strong acid soils than when applied with nonalkaline biosolids. In another study, Luo and Christie [39] found increased yield of barley when amending a mild to strong acid sandy loam ( $\mathrm{pH} 4.5)$ soil with alkalinestabilised biosolids at $33.5 \mathrm{t}$ dry matter $\mathrm{ha}^{-1}$. In this study, fly-ash, a liming material resulting from coal combustion, was used for alkaline stabilisation. The liming effect of the modified biosolids increased soil $\mathrm{pH}$ by about $1.2-1.5$ units and as a consequence $\mathrm{Al}$ toxicity was reduced (from 4.0 to $0.1 \mathrm{cmol} \mathrm{kg}^{-1}$ ) in barley crop that was grown under strong acid sandy soil conditions.

Manipulating soil $\mathrm{pH}$ using alkaline stabilised biosolids helped suppress the soilborne pathogenic nematode, Meloidogyne incognita, in addition to supplying plant nutrients in a loamy sand soil [41]. In this study, N-Viro soils, a commercial product developed by mixing biosolids with alkaline byproducts (such as coal ash, cement, and lime kiln dusts), was used as a soil amendment, further amended with urea fertiliser and kept for 5 days in incubation. It suppressed nematode growth which was directly associated with higher $\mathrm{NH}_{3}$ production from urea and indirectly through increased soil $\mathrm{pH}$ by the alkaline biosolids.

Studies have also focused on mixing a variety of materials with biosolids to alter the nutrient or heavy metal availability that enhanced safe nutrient levels [42]. For example, there were benefits when biosolids were mixed with river sediments and/or composted with other organic materials such as oats straw and cattle manures [43-46]. A greenhouse study showed a significant increase in plant growth when soil was amended with a mixture of sediment and biosolids compared with application of either sediment or biosolids alone [44]. In this case, heavy metals were within an accepted range in the plant tissues when grown with the mixture. However, the impact on soil microbial communities was not assessed in this study. A formula that contains a mixture of biosolids with river-sediments was investigated for recycling nutrients from biosolids using native grasses [46]. It was suggested that mixing of biosolids with river sediments has potential benefit in increasing organic and inorganic nutrient content of the sediments and in improving sediment quality; the reclamation of damaged soils was improved at a field scale for the combination of biosolids and sediments compared with either sediment or biosolids alone. This study confirmed that a mixture of river sediment improved soil texture and increased plant available nutrients, microbial biomass, and plant growth. The mixture altered microbial community composition, with relative increases in Gramnegative bacteria and decreases in Gram-positive bacteria, fungi, and actinomycetes [46].

1.2. Research on LaBC in Western Australia. LaBC is a slow release organic amendment [47]. It is a typical modified clay and lime amended biosolids product (LaBC: lime-amended BioClay) formulated for use in acid sandy soils of the Swan Coastal Plain in Western Australia [47]. It has been demonstrated that LaBC has lower chemical contaminant threshold concentrations than that required for unrestricted use ( $\mathrm{C} 1$ classification) based on Western Australian Biosolids Guidelines [47, 48]. This is a consequence of the severe dilution of the biosolids in a lime and clay blended product. LaBC has a number of desirable soil-organic amendment qualities such as improving water and nutrient retention capacity of coarse textured soils. It has been shown to alter soil $\mathrm{pH}\left(\mathrm{CaCl}_{2}\right.$ extract) from 5.0 to $\mathrm{pH}$ of 8.0 as the productblend is strongly alkaline ( $\mathrm{pH}$ of 10.0$)$ due to the presence of lime [48]. In addition, $\mathrm{LaBC}$ is rich in clay and organic matter and rich with significant amounts of plant nutrients from the biosolids component [48]. The clay material blended in the LaBC is not hydrophobic and has potential to reduce the severity of hydrophobicity of sandy soils when applied at rates greater than 50 tonnes per hectare [47-49].

The suitability of LaBC as a soil organic amendment has been investigated at both laboratory and field scales to evaluate the safe recycling of biosolids in the environment [48-52]. The chemical effects of LaBC in providing agronomical benefits for crop growth have been extensively demonstrated under both field and laboratory conditions [47, 48,53 ]. Furthermore, field experiments have been initiated to investigate nutrient leaching risks after its applications and to study the long-term effect of LaBC using ryegrass [47, 50, 53]. However, the overall effect of $\mathrm{LaBC}$ on soil microbiological fertility was not considered in these studies and this requires investigation before the product is recommended for wide application in the soils of Ellen Brook catchment [54]. 


\section{Major Problems in Sandy Soils and Their Causes}

2.1. Soil Acidity. In south-western Australia, soil acidification is widespread and results in part from inefficient use of nitrogen in agriculture that enhances natural acidification processes $[40,47,55]$. Soil acidification from pasture and cropping affects about $3 \mathrm{M}$ ha of cropped land in the Mediterranean region of Australia [56]. Soil acidity (mostly $\mathrm{pH}$ less than 5.5) commonly develops in agricultural lands in association with building-up of organic matter, frequent application of mineral fertilisers, and leaching of nitrate [55]. Acidity also creates $\mathrm{Al}$ and $\mathrm{Mn}$ toxicity to plants $[9,39,57]$ and inhibits root nodulation and $\mathrm{N}$-fixation in legumes $[1,58-$ 61]. Low soil $\mathrm{pH}$ reduces the growth and activities of many soil microorganisms and this eventually leads to lower plant productivity due to decreased organic matter decomposition and mineralisation $[62,63]$. Historically, agricultural lime or other liming materials are applied at rates of $1-1.5 \mathrm{t} \mathrm{ha}^{-1}$ every 7-10 years in Australia based on soil buffering capacity and properties of liming materials, towards increasing soil $\mathrm{pH}$ for favourable plant productivity $[40,55,64]$.

2.2. Soil Water Repellence. Soil water repellence develops by the accumulation of plant and fungi derived hydrophobic organic coating on the sand grains $[6,65,66]$. Soil organic materials, in particular stable humic fraction, have been identified as main reason for water repellence on sand grains [67-69]. Water repellence in soils of south-western Australia occurs mostly in coarse-textured sandy soils and sandy duplex soils that have less than $5 \%$ clay on the surface $[1,70$, 71]. Water repellent soils have been investigated worldwide [67], for example, in USA, Florida and California, in New Zealand, and in Australia, and the involvement of organic matter is considered a factor associated with water repellence in all of these regions $[67,69]$. In Australia, more than 5 million ha of land has been characterised with water repellent sands, including those on the Swan Coastal Plain $[6,72$, 73]. Several studies also reported accumulation of wax-like long chain fatty acids of either fungal or plant origin and other similar types of organic compounds of plant origin, in particular, from Eucalyptus spp. as causes of water repellence $[66,74-76]$. The nonwetting nature of soil increases the risk of water and wind erosion. Some 2 million ha of sandy soils across southern Australia is affected by wind erosion and leads to severe productivity losses $[1,6,66,77]$. Nonuniform wetting of soil, often associated with nonwetting properties, results in severe yield reduction in agricultural land due to poor germination of seeds and less plant establishment in these regions $[6,66,69,78,79]$.

2.3. Nutrient Leaching. Excessive fertilisation can accelerate nutrient leaching in sandy agricultural soils and has potential to cause environmental problems such as eutrophication [80], soil acidity [81], and ground water pollution [82, 83]. For instance, commercial bags of garden and all-purpose fertilisers should not contain more than $2 \%$ and $1 \%$ of $\mathrm{P}$, respectively, according to the Environment Protection regulations guidelines of Western Australia. Nutrient retention capacity of sandy soils is generally very poor with excessive fertilisation in sandy soils increasing nutrient leaching [84] and freedraining sandy soils can threaten nearby water bodies.

For the Swan Coastal Plain in south-western Australia, nutrient leaching is a primary cause of ground water pollution $[85,86]$. The contaminated groundwater further affects surface water quality of the river systems and surrounding lakes [87, 88]. Dissolved inorganic $\mathrm{N}$ and bioavailable $\mathrm{P}$ are generally the excessive nutrients that promote algal growth in water bodies [89-91] which can be hazardous to aquatic organisms and human health [92]. Maximum acceptable limit for nitrate in drinking water is $10 \mathrm{mg} \mathrm{L}^{-1}$ according to World Health Organization. Hence, efficiency in application of nutrients should be the main objective in designing fertiliser plans for coarse-textured agricultural soils [86-88].

\section{Potential Sandy Soil Management Using Amendments}

3.1. Clay. Clay spreading is a sustainable and economically viable method for long-term remediation of water repellence in sandy soils [93] and claying is a common term used for top dressing transported clay materials on surface of the sandy soil, which is a practice used in south-western Australia. Increases in clay content of even $1-2 \%$ can play a crucial role in prevention of water repellence in a very sandy soil $[70,71]$. Water repellence can be minimised by applying a higher amount of clay minerals (up to $100 \mathrm{tha}^{-1}$ ) in sandy soils $[70,93,94]$ and, in particular, use of kaolinite clay on a very severely water repellent soil has been shown as the best clay in overcoming water repellence [95]. Clay is attributed for its potential in increasing surface area that causes improved soil wettability $[93,95]$. Conventionally, clay has been added at rates of $40-250 \mathrm{tha}^{-1}$ on sandy soils in southern and south-western Australia to overcome the water repellence $[70,93,94]$. However, the technique of claying is continually being modified to attain maximum economic returns from degraded agricultural lands in various regions of Australia [6, 93].

3.2. Lime. Lime addition has been shown to decrease water repellence in sandy soils and liming is generally used as a common term for soil lime application [6, 69]. It has been demonstrated that lime added at rates of $3-15 \mathrm{tha}^{-1}$ decreased water repellence under irrigated sandy soils in WA [6]. While liming is generally practiced to increase soil $\mathrm{pH}$ in acid soils, it has also been shown to increase microbial biomass and soil respiration that is associated with acid-intolerant microorganisms [62, 63, 96]. Increased soil microbial biomass and activities due to liming, in turn, increase mineralisation and nutrient availability for better plant productivity $[63,97]$. However, increases in microbial activity, including mineralisation rates, are not consistent under different soil management systems [98, 99]. In a comparison of the practices of claying and liming, it was shown that lime applied up to $5 \mathrm{tha}^{-1}$ could be used as an alternative for clay applied at $100 \mathrm{tha}^{-1}$ in a sandy soil [6]. However, a combination of lime with clay was not included 
in this investigation. Furthermore, higher soil $\mathrm{pH}$ has been shown to increase the abundance of wax-degrading bacteria corresponding with a reduction in the hydrophobic layer that causes water repellence in sandy soil [6]. Therefore, management practices that decrease water repellence under acid soil conditions could be strategically planned by choosing a combination of soil ameliorants.

3.3. Biochar. Biochar is a byproduct resulting from pyrolysis (process of thermal degradation in the absence of air) of organic materials [100, 101]. Besides being popularly known for its carbon sequestration values [102-106], its soil ameliorating and agronomic values have equally attracted research attention worldwide [107-111]. Biochar characteristics differ (e.g., $\mathrm{pH}$ 6.2-9.9) with the various feedstock sources used under different production temperatures (260$700^{\circ} \mathrm{C}$ ) [101]. There is no supply of direct plant nutrients available in biochar to help enriching soil fertility status $[101,112]$. However, the varying micro- and macropore structures of biochar (from nano-, $<0.9 \mathrm{~nm}$, micro-, $<2 \mathrm{~nm}$, to macropores, $>50 \mathrm{~nm}$ ) [113] help increase soil surface area and retention of nutrients supplied through other fertiliser sources. These factors increase soil agronomic values and plant productivity in addition to providing a physical niche for beneficial soil microorganisms [101, 108, 114-116]. Therefore, biochar has potential for improving soil fertility by manipulating aspects of soil physical, chemical, and biological properties when amended with a range between 0.5 and $135 \mathrm{tha}^{-1}[101,110,117]$. The nature of the manipulation depends on the origin of the biochar, as not all forms of biochar have the same characteristics [101].

The physical structure of biochar manipulates soil macroand microporosity and provides microhabitat for soil microbial communities including fungi (arbuscular mycorrhizal (AM) fungi) and bacteria [108, 110, 118-120]. Management of microbial communities in agricultural soils depends on provision of soil conditions that suit their growth and activity [121]. Several studies have shown increased colonisation of AM fungi corresponding with biochar application $[119,122$, 123]. The biochar particles buried in soil increased availability of micropore space which has been claimed to provide protective microhabitat for growth and extension of the hyphae of AM fungi into the biochar $[124,125]$. The extended extraradical hyphae can thereby increase plant $\mathrm{P}$ uptake from soil [126-128]. Similarly, rhizobacterial activity and symbiotic nitrogen fixation with legume plants can be increased in association with biochar application [129]. Biochar applied to soil can protect rhizobia in pores $<50 \mathrm{~mm}$ from predation in soils with low clay content and caused improved nitrogen fixation [130].

In addition to creating favourable microhabitat as a direct benefit to microbial communities, biochar application can help create favourable soil chemistry for their survival and plant uptake indirectly [124, 131-134]. For example, increased atmospheric $\mathrm{N}_{2}$ fixation was observed in biocharapplied legume root nodules through improved symbiotic association with soilborne rhizobia $[124,129]$. These effects are associated with a suppressive effect of soluble forms of $\mathrm{N}$ in soil solution on the $\mathrm{N}_{2}$ fixation, while available soil $\mathrm{P}$ can provide supportive effect in the bacterial growth when soils are amended with biochar [118, 124, 135]. It has also been suggested that biochar may have a role in presence of fertilisers if they stimulate the available native strains of beneficial microbial communities in the soil $[112,132]$.

From an environmental perspective, soil amendment with some forms of biochar has potential to minimise nearby surface and ground water pollution [112, 136-141] through the mechanism of adsorption of dissolved organic carbon [119], $\mathrm{NH}_{4}^{+}[112,142,143]$, and trace metals in leachates [144]. Soil amendment with biochar may also reduce heavy metal accumulation due to frequent applications of other organic amendments (e.g., biosolids) that contain potential metal contaminants [100]. Some studies have demonstrated increased bioavailability of plant nutrients and uptake of $\mathrm{P}$, $\mathrm{K}, \mathrm{Ca}, \mathrm{Zn}$, and $\mathrm{Cu}$ after charcoal application, while decreased $\mathrm{N}$ leaching has also been observed [112, 145-149]. A range of specific soil physical, chemical, or microbiological properties, therefore, may be manipulated by developing a careful soil amendment strategy with biochar, although not all biochars are expected to function in the same manner [110]. For instance, short-term negative impacts of biochars have also been attributed to volatile toxic organic compounds and phytotoxic salts that could have caused reduced microbial biomass C [143] and plant root growth activities, respectively [110].

3.4. Interactions between Clay, Biochar, and Biosolids. Characteristics of soil amendments are inherently different. They determine key roles in altering soil $\mathrm{N}$ mineralisation processes when applied independently or when coapplied with other amendments. While biosolids are usually considered as a source of nutrients (especially $\mathrm{N}$ ) that accelerate $\mathrm{N}$ release into soil $[150,151]$, other amendments such as clay and biochar act as potential sinks and lead to retention of soil $\mathrm{N}$ and decrease $\mathrm{N}$ leaching into the immediate environment through various mechanisms $[101,110]$.

Dempster et al. [141] compared the efficiency of clay and biochar in achieving decreased $\mathrm{N}$ leaching in coarse-textured soils in south-western Australia. A lysimeter column study was investigated for 21 days after amending soil independently with $25 \mathrm{t} \mathrm{ha}^{-1}$ of clay and biochar with different application methods. Both amendments significantly decreased cumulative $\mathrm{NH}_{4}{ }^{+}$leaching by about $20 \%$ and $\mathrm{NO}_{3}{ }^{-}$leaching by about $25 \%$. However, biochar significantly decreased $\mathrm{NO}_{3}{ }^{-}$leaching more than clay did and this was mainly associated with a larger difference in anion retention capacity. While clay lacked the ability to retain $\mathrm{NO}_{3}{ }^{-}$, the biochar used in this study had a dual role in $\mathrm{NO}_{3}{ }^{-}$sorption processes and increased water holding capacity [141]. Moreover, the capacity of biochar to control $\mathrm{N}$ leaching in this case was associated with decreased nitrification values in amended soil as shown in a previous study [143].

Previous studies with biochar identified the same two important mechanisms as described above, which were attributed as potential reasons for decreased $\mathrm{N}$ leaching capacity. First the high $\mathrm{NO}_{3}{ }^{-}$retention was due to positive charge of biochar [152]. Second, decreased $\mathrm{NH}_{4}{ }^{+}$leaching was due to improved gravimetric water holding capacity of 
soil rather than its sorption effect onto the biochar $[112,141$, 142].

Coapplication of clay with other organic composts has been shown to be a beneficial soil management practice in coarse textured soils of south-western Australia and for similar environments [153]. As discussed above for the experiments of Dempster et al. [141], a preliminary 21-day study showed that clay also had a significant effect on decreasing $\mathrm{N}$ leaching in sandy soils and its effect was comparable with that of biochar. However, that study did not investigate whether the nutrients retained by clay or biochar were plant available or whether they helped increase the efficiency of use of fertiliser in the amended agricultural soil. Further, these studies did not investigate the combined effect of clay and biochar on plant growth nor did they investigate the combined influence on slow release fertiliser such as biosolids when they are coapplied in multiple combinations.

The inclusion of biochar helped decrease nitrate leaching from biosolids amended soils over five months [42]. A lysimeter column leaching study was established with ryegrass and amended with combinations of biochar (102 $\mathrm{tha}^{-1}$ equivalent) and biosolids ( 600 and $1200 \mathrm{~kg} \mathrm{~N} \mathrm{ha}^{-1}$ equivalent) in two types of silty loam soils. The inclusion of biochar and biosolids together resulted in significantly less nitrate leaching than in the biosolids alone treatment and suggested for higher rate application of the mixtures to rebuild degraded soils. However, developing an optimum mixture ratio and identification of the mechanisms responsible for alteration in the nitrogen cycle were not addressed in this study. There is potential that biosolids applied at a level equivalent to $1200 \mathrm{~kg} \mathrm{Nha}^{-1}$ could become an additional risk associated with excessive leaching in conditions similar to those used by Knowles et al. [42].

The use of clay minerals such as Na-bentonite and Cabentonite could be a potential tool for immobilising up to $70 \%$ of bioavailable form of heavy metals such as $\mathrm{Zn}, \mathrm{Cd}$, $\mathrm{Cu}$, and $\mathrm{Ni}$ in sewage sludge contaminated soil [154]. In an incubation study of more than 110 days, soil biological parameters such as microbial biomass $\mathrm{C}$, respiration, and organic $\mathrm{C}$ mineralisation rate were higher in clay-amended soil, and this was associated with reduced heavy metal toxicity on the microbial parameters.

In comparison to the studies considered above, the combination of lime, clay, and biosolids makes LaBC a unique biosolids product with potential for benefits to be multiplied when coapplied with biochar. This raises scope of investigating the biosolids amendment in combination with other $\mathrm{N}$ absorbing ameliorants [54].

\section{Soil Microbial Properties}

A shift in soil microbial communities can be associated with soil textural changes. For example, mineralization is influenced by soil texture and structure as they both affect the aeration status, the physical distribution of organic materials, and other physical, chemical, and biological environmental characteristics of soil [155-157]. Bach et al. [157] demonstrated that soil microbial community (using phospholipid fatty acid, PLFA method) responses to grassland restoration were moderated by soil texture during the monitoring of grassland ecosystem recovery for 19 years. Nevertheless, other studies have claimed that soil texture had no significant effect on the decomposition rate and/or microbial community structures when soils with contrasting textures were amended with carbon substrates such as low molecular weight carbon sources (e.g., glucose) [158-160]. However, addition of clay to soil could create new microhabitats, particularly if it has low clay content [161]. The added clay can contribute to an increase in soil microbial biomass [156, 162-164]. Despite conflicting observations, the respiration rate of preincubated soils could, at least to some extent, depend on the replacement of the labile substrate from soil organic matter, and the amount applied could decrease when soil texture is altered, for example, when texture is modified with increasing clay content [165].

Soil texture, in particular clay content, is an important factor which influences organic matter decomposition including the labile pool of carbon, that is, microbial biomass $[166,167]$. Clay can physically protect living (microbial biomass $\mathrm{C}$ ) and nonliving soil organic matter and causes reduced decomposition and $\mathrm{CO}_{2}$ evolution in soils $[165,168$, 169 ]. The direct physical protection of organic matter is possibly achieved by surface adsorption and entrapment of organic matter between clay layers and thereby prevents or reduces the rate of decomposition by soil microorganisms [170-173]. On the other hand, clay can protect the active component of living organic matter (known as soil microflora) by physically confining them in small pores, making them less active and protecting them against predation by soil protozoa [174]. Thus, clay is assumed to play a major role in minimising soil C mineralisation.

Umar [167] investigated the protective effect of clay minerals $(5,10,20$, and $40 \% \mathrm{w} / \mathrm{w})$ on wheat residue $(2 \%$ $\mathrm{w} / \mathrm{w})$ decomposition in commercial sand associated with decreased C mineralisation through 32-day incubation study. Clay applied at $<20 \%$ decreased cumulative respiration until 28 days and this decreased $\mathrm{C}$ mineralisation was associated with a clay binding effect on organic matter. However, 20 and $40 \%$ clay increased the $\mathrm{C}$ mineralisation after 18 days which was associated with higher water retention capacity and corresponding increase in higher activities of microbial communities which were unable to survive in lightertextured soils.

\section{Conclusions}

Biosolids disposal on soils with water repellent, acid, and coarse-textured characteristics will need to ensure that any nutrients from the modified product do not become a potential threat to the environment. While the potential agronomical influences of modified biosolids products use have been identified in terms of altering soil physical and chemical properties, their use in improving soil fertility with relevance to microbiological parameters has not been studied critically.

The potential benefits of combining biosolids with other amendments can include reduction in microbial processes such as mineralisation of organic matter. This could be 
beneficial if it led to slow release of nutrients from biosolids. There is a need for further investigation of the $\mathrm{C}$ and $\mathrm{N}$ mineralisation patterns and related changes in soil microbiological properties when combinations of clay, lime, and biosolids and/or biochar are applied to sandy soil. This information would enable greater understanding of how modified biosolids products influenced the short- and longterm dynamics of soil nutrient cycling following application to soil. It would clarify effects of plant rotation, in terms of the build-up of soil N, microbial biomass $\mathrm{N}$, and bioavailability of $\mathrm{N}$. Investigation of impacts on soil microbiological processes across the scales of laboratory incubation through a series of glasshouse and field experiments would contribute to modification of biosolids products to suit particular soils, plants, agricultural management systems, and environmental conditions.

\section{Conflict of Interests}

The authors declare that there is no conflict of interests regarding the publication of this paper.

\section{Acknowledgments}

Sanjutha Shanmugam was awarded a Ph.D. Scholarship by The University of Western Australia with financial support of the Water Corporation of Western Australia. LaBC is a registered trademark product of the Water Corporation of Western Australia (WA, Australia).

\section{References}

[1] A. D. Rovira, "Dryland mediterranean farming systems in Australia," Australian Journal of Experimental Agriculture, vol. 32, no. 7, pp. 801-809, 1992.

[2] Bureau of Meteorology, 2012, http://www.bom.gov.au/jsp/ncc/ climate_averages/rainfall/index.jsp.

[3] G. Moore and P. Blackwell, "Water repellence," in Soil Guide, G. Moore, Ed., pp. 53-63, Agriculture Western Australia, 1998.

[4] R. F. Isbell, The Australian Soil Classification, CSIRO Publishing, Melbourne, Australia, 1996.

[5] R. J. Harper, T. J. Hatton, D. S. Crombie et al., Phase Farming with Trees: A Scoping Study of Its Potential for Salinity Control, Soil Quality Enhancement and Farm Income Improvement in Dryland Areas of Southern Australia, Rural Industries Research and Development Corporation, Canberra, Australia, 2000.

[6] M. M. Roper, "Managing soils to enhance the potential for bioremediation of water repellency," Australian Journal of Soil Research, vol. 43, no. 7, pp. 803-810, 2005.

[7] R. P. Singh and M. Agrawal, "Potential benefits and risks of land application of sewage sludge," Waste Management, vol. 28, no. 2, pp. 347-358, 2008.

[8] J. Bradley, "New Zealand," in Global Atlas of Excreta, Wastewater Sludge, and Biosolids Management: Moving forward the Sustainable and Welcome Uses of a Global Resource, R. J. LeBlanc, P. Matthews, and R. P. Richard, Eds., pp. 447-454, United Nations Human Settlements Programme (UN-HABITAT), Nairobi, Kenya, 2008.
[9] J. J. Sloan and N. T. Basta, "Remediation of acid soils by using alkaline biosolids," Journal of Environmental Quality, vol. 24, no. 6, pp. 1097-1103, 1995.

[10] M. J. Kelty, F. D. Menalled, and M. M. Carlton, "Nitrogen dynamics and red pine growth following application of pelletized biosolids in Massachusetts, USA," Canadian Journal of Forest Research, vol. 34, no. 7, pp. 1477-1487, 2004.

[11] H. Wang, S. L. Brown, G. N. Magesan et al., “Technological options for the management of biosolids," Environmental Science and Pollution Research, vol. 15, no. 4, pp. 308-317, 2008.

[12] S. Alcantara, D. V. Pérez, M. R. A. Almeida, G. M. Silva, J. C. Polidoro, and W. Bettiol, "Chemical changes and heavy metal partitioning in an oxisol cultivated with Maize (Zea mays, L.) after 5 years disposal of a domestic and an industrial sewage sludge," Water, Air, and Soil Pollution, vol. 203, no. 1-4, pp. 316, 2009.

[13] M. C. Antolín, I. Pascual, C. García, A. Polo, and M. SánchezDíaz, "Growth, yield and solute content of barley in soils treated with sewage sludge under semiarid Mediterranean conditions," Field Crops Research, vol. 94, no. 2-3, pp. 224-237, 2005.

[14] I. Pascual, M. C. Antolín, C. García, A. Polo, and M. SánchezDíaz, "Effect of water deficit on microbial characteristics in soil amended with sewage sludge or inorganic fertilizer under laboratory conditions," Bioresource Technology, vol. 98, no. 1, pp. 29-37, 2007.

[15] G. C. Sigua, "Recycling biosolids and lake-dredged materials to pasture-based animal agriculture: alternative nutrient sources for forage productivity and sustainability: a review," in Sustainable Agriculture, E. Lichtfouse, Ed., Part 5, pp. 495-517, Springer, Dordrecht, The Netherlands, 2009.

[16] P. C. Brookes and S. P. McGrath, "Effects of metal toxicity on the size of the soil microbial biomass," Journal of Soil Science, vol. 35, no. 2, pp. 341-346, 1984.

[17] K. E. Giller and S. P. McGrath, "Muck, metals and microbes," New Scientist, vol. 124, no. 1689, pp. 31-32, 1989.

[18] K. Chander and P. C. Brookes, "Effects of heavy metals from past applications of sewage sludge on microbial biomass and organic matter accumulation in a sandy loam and silty loam U.K. soil," Soil Biology and Biochemistry, vol. 23, no. 10, pp. 927-932, 1991.

[19] P. R. Hirsch, M. J. Jones, S. P. McGrath, and K. E. Giller, "Heavy metals from past applications of sewage sludge decrease the genetic diversity of rhizobium leguminosarum biovar trifolii populations," Soil Biology and Biochemistry, vol. 25, no. 11, pp. 1485-1490, 1993.

[20] G. H. Dar and M. M. Mishra, "Influence of cadmium on carbon and nitrogen mineralization in sewage sludge amended soils," Environmental Pollution, vol. 84, no. 3, pp. 285-290, 1994.

[21] E. Smolders, J. Buekers, I. Oliver, and M. J. McLaughlin, "Soil properties affecting toxicity of zinc to soil microbial properties in laboratory-spiked and field-contaminated soils," Environmental Toxicology and Chemistry, vol. 23, no. 11, pp. 2633-2640, 2004.

[22] K. E. Giller, E. Witter, and S. P. McGrath, “Toxicity of heavy metals to microorganisms and microbial processes in agricultural soils: a review," Soil Biology and Biochemistry, vol. 30, no. 10-11, pp. 1389-1414, 1998.

[23] K. E. Giller, E. Witter, and S. P. McGrath, "Assessing risks of heavy metal toxicity in agricultural soils: do microbes matter?" Human and Ecological Risk Assessment, vol. 5, no. 4, pp. 683689, 1999. 
[24] K. E. Giller, E. Witter, and S. P. McGrath, "Heavy metals and soil microbes," Soil Biology and Biochemistry, vol. 41, no. 10, pp. 2031-2037, 2009.

[25] H. F. Li, C. Gray, C. Mico, F. J. Zhao, and S. P. McGrath, "Phytotoxicity and bioavailability of cobalt to plants in a range of soils," Chemosphere, vol. 75, no. 7, pp. 979-986, 2009.

[26] V. F. Meyer, E. F. Redente, K. A. Barbarick, and R. Brobst, "Biosolids applications affect runoff water quality following forest fire," Journal of Environmental Quality, vol. 30, no. 5, pp. 1528-1532, 2001.

[27] A. L. Shober and J. T. Sims, "Phosphorus restrictions for land application of biosolids: current status and future trends," Journal of Environmental Quality, vol. 32, no. 6, pp. 1955-1964, 2003.

[28] T. Krogstad, T. A. Sogn, Å. Asdal, and A. Sæbø, "Influence of chemically and biologically stabilized sewage sludge on plantavailable phosphorous in soil," Ecological Engineering, vol. 25, no. 1, pp. 51-60, 2005.

[29] M. T. E. Smith and M. Tibbett, "Nitrogen dynamics under Lolium perenne after a single application of three different sewage sludge types from the same treatment stream," Bioresource Technology, vol. 91, no. 3, pp. 233-241, 2004.

[30] ANZECC and ARMCANZ, Australian and New Zealand Guidelines for Fresh and Marine Water Quality. The Guidelines, vol. 1, Australian and New Zealand Environment and Conservation Council and Agriculture and Resource Management Council of Australia and New Zealand, Canberra, Australia, 2000.

[31] W. D. Joshua, D. L. Michalk, I. H. Curtis, M. Salt, and G. J. Osborne, "The potential for contamination of soil and surface waters from sewage sludge (biosolids) in a sheep grazing study, Australia," Geoderma, vol. 84, no. 1-3, pp. 135-156, 1998.

[32] S. R. Smith, V. Woods, and T. D. Evans, "Nitrate dynamics in biosolids treated soils. I. Influence of biosolids type and soil type," Bioresource Technology, vol. 66, no. 2, pp. 139-149, 1998.

[33] S. R. Smith, V. Woods, and T. D. Evans, "Nitrate dynamics in biosolids-treated soils. II. Thermal-time models of the different nitrogen pools," Bioresource Technology, vol. 66, no. 2, pp. 151$160,1998$.

[34] S. M. Eldridge, K. Y. Chan, Z. H. Xu, C. R. Chen, and I. Barchia, "Plant-available nitrogen supply from granulated biosolids: implications for land application guidelines," Australian Journal of Soil Research, vol. 46, no. 5, pp. 423-436, 2008.

[35] J. A. Ippolito, K. A. Barbarick, and R. B. Brobst, "Fate of biosolids $\mathrm{Cu}$ and $\mathrm{Zn}$ in a semi-arid grassland," Agriculture, Ecosystems and Environment, vol. 131, no. 3-4, pp. 325-332, 2009.

[36] R. Mata-González, R. E. Sosebee, and C. Wan, "Effect of types of biosolids and cattle manure on desert grass growth," Rangeland Ecology and Management, vol. 59, no. 6, pp. 664-667, 2006.

[37] D. M. Sullivan, Biosolids Increase Grass Yield, Grass Quality and Soil Fertility in Dryland Pasture, Bureau of Environmental Services Monitoring Data, City of Portland. Report by Oregon State University, 2008.

[38] A. W. Schumann and M. E. Summer, "Formulation of environmentally sound waste mixtures for land application," Water, Air, and Soil Pollution, vol. 152, no. 1-4, pp. 195-217, 2004.

[39] Y. Luo and P. Christie, "Alleviation of soil acidity and aluminium phytotoxicity in acid soils by using alkaline-stabilised biosolids," Pedosphere, vol. 12, no. 2, pp. 185-188, 2002.

[40] D. Pritchard, H. Rigby, and D. Collins, "Research studies on the impact of the agricultural application of Lime-amended Biosolids," Final Report to Water Corporation CN-06-12930, 2010.
[41] I. A. Zasada and M. Tenuta, "Alteration of the soil environment to maximize Meloidogyne incognita suppression by an alkalinestabilized biosolid amendment," Applied Soil Ecology, vol. 40, no. 2, pp. 309-317, 2008.

[42] O. A. Knowles, B. H. Robinson, A. Contangelo, and L. Clucas, "Biochar for the mitigation of nitrate leaching from soil amended with biosolids," Science of the Total Environment, vol. 409, no. 17, pp. 3206-3210, 2011.

[43] C. Elvira, L. Sampedro, E. Benítez, and R. Nogales, "Vermicomposting of sludges from paper mill and dairy industries with Eisena andrei: a pilot-scale study," Bioresource Technology, vol. 63, no. 3, pp. 205-211, 1998.

[44] D. R. Diaz and R. Darmody, "Illinois River dredged sediment and biosolids used as greenhouse soil mixtures," WMRC Reports, 2004.

[45] S. M. Contreras-Ramos, E. M. Escamilla-Silva, and L. Dendooven, "Vermicomposting of biosolids with cow manure and oat straw," Biology and Fertility of Soils, vol. 41, no. 3, pp. 190-198, 2005.

[46] J. J. Kelly, E. Favila, L. S. Hundal, and J. C. Marlin, "Assessment of soil microbial communities in surface applied mixtures of Illinois River sediments and biosolids," Applied Soil Ecology, vol. 36, no. 2-3, pp. 176-183, 2007.

[47] R. Humphries, T. Long, K. Walton, and D. Allen, "From waste to water quality-opportunities for achieving sustainable urban development on the sandy soils of the Swan coastal plain, Western Australia," in Proceedings of the 6th International Water Sensitive Urban Design Conference (WSUD '09), Western Australia, Australia, 2009.

[48] ChemCentre, Evaluation of the Effectiveness and Environmental Risks Following Application of Lime-Amended Biosolids to Bassendean Sands-Part 3: Blends with Clay, 2009.

[49] S. Shanmugam, L. K. Abbott, and D. V. Murphy, "Clay addition to lime-amended biosolids overcomes water repellence and provides nitrogen supply in an acid sandy soil," Biology and Fertility of Soils, vol. 50, pp. 1047-1059, 2014.

[50] D. Allen and K. Walton, "Evaluation of the effectiveness and environmental risks following the application of Limeamended Biosolids to Bassendean sands. Part 3. Blends with clay," Report to the Water Corporation, Chemistry Centre, Bentley, Australia, 2010.

[51] R. Humphries, "Request of approval to classify Lime-amended BioClay for unrestricted use (Based on the Victorian secondary beneficial reuse notification protocol)," Water Corporation, unpublished document, 2010.

[52] E. M. Davison and F. C. S. Tay, Survival of Phytophthora cinnamomi and P. multivora in Lime-Amended Bioclay (LaBC) and LaBC Plus Organic Material, Department of Environment and Agriculture, Curtin University, Perth, Wash, USA, 2011.

[53] R. Ovens, Report on LaBC Field Trial to Water Corporation, Water Corporation, Perth, Australia, 2009.

[54] S. Shanmugam, Impact of LaBC on microbiological processes in coarse textured soil [Ph.D. thesis], School of Earth and Environment, The University of Western Australia, Western Australia, Australia, 2014.

[55] G. Moore, P. Dolling, B. Porter, and L. Leonard, "Chemical factors affecting plant growth: soil acidity," in Soil GuideA Handbook for Understanding and Managing Agricultural Soils, G. Moore, Ed., pp. 127-140, Department of Agriculture, Bulletin, Perth, Australia, 1998. 
[56] D. R. Coventry, "Acidification problems of duplex soils used for crop-pasture rotations," Australian Journal of Experimental Agriculture, vol. 32, no. 7, pp. 901-914, 1992.

[57] A. Farhoodi and D. R. Coventry, "Field crop responses to lime in the mid-north region of South Australia," Field Crops Research, vol. 108, no. 1, pp. 45-53, 2008.

[58] P. D. Cregan, J. R. Hirth, and M. K. Conyers, "Amelioration of soil acidity by liming and other amendments," in Soil Acidity and Plant Growth, A. D. Robson, Ed., pp. 205-264, Academic Press, Marrickville, Australia, 1989.

[59] M. B. Peoples, D. F. Herridge, and J. K. Ladha, "Biological nitrogen fixation: an efficient source of nitrogen for sustainable agricultural production?" Plant and Soil, vol. 174, no. 1-2, pp. 328, 1995.

[60] M. B. Peoples, D. M. Lilley, V. F. Burnett, A. M. Ridley, and D. L. Garden, "Effects of surface application of lime and superphosphate to acid soils on growth and $\mathrm{N}_{2}$ fixation by subterranean clover in mixed pasture swards," Soil Biology and Biochemistry, vol. 27, no. 4-5, pp. 663-671, 1995.

[61] K. D. Ritchey, D. P. Belesky, and J. J. Halvorson, “Soil properties and clover establishment six years after surface application of calcium-rich by-products," Agronomy Journal, vol. 96, no. 6, pp. 1531-1539, 2004.

[62] T.-H. Anderson, "The influence of acid irrigation and liming on the soil microbial biomass in a norway spruce (Picea abies [L.] K.) stand," Plant and Soil, vol. 199, no. 1, pp. 117-122, 1998.

[63] T. Filep and T. Szili-Kovács, "Effect of liming on microbial biomass carbon of acidic arenosols in pot experiments," Plant, Soil and Environment, vol. 56, no. 6, pp. 268-273, 2010.

[64] A. Miller, "Agricultural lime use in Western Australia 1994/95 to 2001/02," in Western Australia Soil Acidity Research and Development Update 2002, pp. 71-77, Department of Agriculture, South Perth, Australia, 2002.

[65] P. D. Hallett, N. A. White, and K. Ritz, "Impact of basidiomycete fungi on the wettability of soil contaminated with a hydrophobic polycyclic aromatic hydrocarbon," Biologia, vol. 61, no. 19, supplement, pp. S334-S338, 2006.

[66] P. D. Hallett, "An introduction to soil water repellency," in Proceedings of the 8th International Symposium on Adjuvants for Agrochemicals (ISAA '07) 6-9 August 2007, R. E. Gaskin, Ed., International Society for Agrochemical Adjuvants (ISAA), Columbus, Ohio, USA, Hand Multimedia, Christchurch, New Zealand, 2007.

[67] F. J. Roberts and B. A. Carbon, "Water repellence in sandy soils of South-Western Australia. II. Some chemical characteristics of the hydrophobic skins," Australian Journal of Soil Research, vol. 10, no. 1, pp. 35-42, 1972.

[68] C. M. M. Franco, P. J. Clarke, M. E. Tate, and J. M. Oades, "Hydrophobic properties and chemical characterisation of natural water repellent materials in Australian sands," Journal of Hydrology, vol. 231-232, pp. 47-58, 2000.

[69] K. Müller and M. Deurer, "Review of the remediation strategies for soil water repellency," Agriculture, Ecosystems and Environment, vol. 144, no. 1, pp. 208-221, 2011.

[70] R. J. Harper and R. J. Gilkes, "Soil attributes related to water repellency and the utility of soil survey for predicting its occurrence," Australian Journal of Soil Research, vol. 32, no. 5, pp. 1109-1124, 1994.

[71] I. McKissock, R. J. Gilkes, and E. L. Walker, "The reduction of water repellency by added clay is influenced by clay and soil properties," Applied Clay Science, vol. 20, no. 4-5, pp. 225-241, 2002.
[72] M. E. Tate, J. M. Oades, and M. Mashum, "Non-wetting soils, natural and induced: an overview and future developments," in The Theory and Practice of Soil Management for Sustainable Agriculture, A Workshop for the Wheat Research Council, pp. 70-77, AGPS, Canberra, Australia, 1989.

[73] P. S. Blackwell, "Management of water repellency in Australia, and risks associated with preferential flow, pesticide concentration and leaching," Journal of Hydrology, vol. 231-232, pp. 384$395,2000$.

[74] D. A. McGhie and A. M. Posner, "Water repellence of a heavy textured western Australia surface soil," Australian Journal of Soil Research, vol. 18, no. 3, pp. 309-323, 1980.

[75] M. Ma'shum, M. E. Tate, G. P. Jones, and J. M. Oades, "Extraction and characterization of water-repellent materials from Australian soils," Journal of Soil Science, vol. 39, no. 1, pp. 99-110, 1988.

[76] C. M. M. Franco, M. E. Tate, and J. M. Oades, "Studies on nonwetting sands. I. The role of intrinsic particulate organic matter in the development of water-repellency in non-wetting sands," Australian Journal of Soil Research, vol. 33, no. 2, pp. 253-263, 1995.

[77] C. M. M. Franco, P. P. Michelsen, and J. M. Oades, "Amelioration of water repellency: application of slow-release fertilisers to stimulate microbial breakdown of waxes," Journal of Hydrology, vol. 231-232, pp. 342-351, 2000.

[78] R. D. Bond, "The influence of the microflora on the physical properties of soils: II. Field studies on water repellent soils," Australian Journal of Soil Research, vol. 2, no. 1, pp. 123-131, 1964.

[79] P. M. King, "Comparison of methods for measuring severity of water repellence of sandy soils and assesment of some factors that affect its measurement," Australian Journal of Soil Research, vol. 19, no. 4, pp. 275-285, 1981.

[80] A. J. P. Smolders, E. C. H. E. T. Lucassen, R. Bobbink, J. G. M. Roelofs, and L. P. M. Lamers, "How nitrate leaching from agricultural lands provokes phosphate eutrophication in groundwater fed wetlands: the sulphur bridge," Biogeochemistry, vol. 98, no. 1-3, pp. 1-7, 2010.

[81] D. P. Heenan and A. C. Taylor, "Soil pH decline in relation to rotatin, tillage, stubble retention and nitrogen fertilizer in S.E.Australia," Soil Use and Management, vol. 11, no. 1, pp. 4-9, 1995.

[82] J. F. Power, R. Wiese, and D. Flowerday, "Managing farming systems for nitrate control: a research review from management systems evaluation areas," Journal of Environmental Quality, vol. 30, no. 6, pp. 1866-1880, 2001.

[83] P. J. Thorburn, J. S. Biggs, K. L. Weier, and B. A. Keating, "Nitrate in groundwaters of intensive agricultural areas in coastal Northeastern Australia," Agriculture, Ecosystems and Environment, vol. 94, no. 1, pp. 49-58, 2003.

[84] G. P. Sparling, L. Barton, L. Duncan et al., "Nutrient leaching and changes in soil characteristics of four contrasting soils irrigated with secondary-treated municipal wastewater for four years," Australian Journal of Soil Research, vol. 44, no. 2, pp. 107116, 2006.

[85] H. B. Pionke, M. L. Sharma, and K.-J. Hirschberg, "Impact of irrigated horticulture on nitrate concentrations in groundwater," Agriculture, Ecosystems and Environment, vol. 32, no. 1-2, pp. 119-132, 1990.

[86] N. R. Viney and M. Sivapalan, "Modelling catchment processes in the Swan-Avon river basin," Hydrological Processes, vol. 15, no. 13, pp. 2671-2685, 2001. 
[87] C. Zammit, M. Sivapalan, P. Kelsey, and N. R. Viney, "Modelling the effects of land-use modifications to control nutrient loads from an agricultural catchment in Western Australia," Ecological Modelling, vol. 187, no. 1, pp. 60-70, 2005.

[88] B. J. Robson, P. A. Bukaveckas, and D. P. Hamilton, "Modelling and mass balance assessments of nutrient retention in a seasonally-flowing estuary (Swan River Estuary, Western Australia)," Estuarine, Coastal and Shelf Science, vol. 76, no. 2, pp. 282-292, 2008.

[89] E. P. Hodgkin and B. H. Hamilton, "Fertilizers and eutrophication in southwestern Australia: setting the scene," Fertilizer Research, vol. 36, no. 2, pp. 95-103, 1993.

[90] J. R. Davis and K. Koop, "Eutrophication in Australian rivers, reservoirs and estuaries-a Southern hemisphere perspective on the science and its implications," Hydrobiologia, vol. 559, no. 1, pp. 23-76, 2006.

[91] M. R. Grace, T. R. Scicluna, C. L. Vithana, P. Symes, and K. P. Lansdown, "Biogeochemistry and cyanobacterial blooms: investigating the relationship in a shallow, polymictic, temperate lake," Environmental Chemistry, vol. 7, no. 5, pp. 443-456, 2010.

[92] A. T. C. Bourke, R. B. Hawes, A. Neilson, and N. D. Stallman, "An outbreak of hepato-enteritis (the Palm Island mystery disease) possibly caused by algal intoxication," Toxicon, vol. 21, no. 3, pp. 45-48, 1983.

[93] M. A. Cann, "Clay spreading on water repellent sands in the south east of South Australia promoting sustainable agriculture," Journal of Hydrology, vol. 231-232, pp. 333-341, 2000.

[94] D. J. Carter and R. E. Hetherington, "Claying of water repellent soils in the Albany region of the South Coast of Western Australia," in Proceedings of the 2nd National Workshop on "Water Repellency in Soils", Perth, Australia, 1994.

[95] P. R. Ward and J. M. Oades, "Effect of clay mineralogy and exchangeable cations on water-repellency in clay-amended sandy soils," Australian Journal of Soil Research, vol. 31, no. 3, pp. 351-364, 1993.

[96] S. P. Neale, Z. Shah, and W. A. Adams, "Changes in microbial biomass and nitrogen turnover in acidic organic soils following liming," Soil Biology \& Biochemistry, vol. 29, no. 9-10, pp. 14631474, 1997.

[97] S. J. Kemmitt, D. Wright, K. W. T. Goulding, and D. L. Jones, "pH regulation of carbon and nitrogen dynamics in two agricultural soils," Soil Biology and Biochemistry, vol. 38, no. 5, pp. 898-911, 2006.

[98] H. Nommik, "Mineralisation of carbon and nitrogen as influenced by additions of phosphate and lime," Acta Agriculturae Scandinavica, vol. 28, no. 3, pp. 221-230, 1978.

[99] J. P. Fuentes, D. F. Bezdicek, M. Flury, S. Albrecht, and J. L. Smith, "Microbial activity affected by lime in a long-term notill soil," Soil and Tillage Research, vol. 88, no. 1-2, pp. 123-131, 2006.

[100] J. Lehmann and S. Joseph, "Biochar for environmental management: an introduction," in Biochar for Environmental Management: Science and Technology, J. Lehmann and S. Joseph, Eds., pp. 1-12, Earthscan, London, UK, 2009.

[101] C. J. Atkinson, J. D. Fitzgerald, and N. A. Hipps, "Potential mechanisms for achieving agricultural benefits from biochar application to temperate soils: a review," Plant and Soil, vol. 337, no. 1, pp. 1-18, 2010.

[102] J. Lehmann, J. Gaunt, and M. Rondon, "Bio-char sequestration in terrestrial ecosystems-a review," Mitigation and Adaptation Strategies for Global Change, vol. 11, no. 2, pp. 403-427, 2006.
[103] J. Lehmann, "A handful of carbon," Nature, vol. 447, no. 7141, pp. 143-144, 2007.

[104] J. Lehmann, "Bio-energy in the black," Frontiers in Ecology and the Environment, vol. 5, no. 7, pp. 381-387, 2007.

[105] J. Lehmann and S. Sohi, "Comment on 'fire-derived charcoal causes loss of forest humus,' Science, vol. 321, no. 5894, p. 1295, 2008.

[106] J. Lehmann, J. O. Skjemstad, S. Sohi et al., "Australian climatecarbon cycle feedback reduced by soil black carbon," Nature Geoscience, vol. 1, no. 12, pp. 832-835, 2008.

[107] C. Steiner, "Soil charcoal amendments maintain soil fertility and establish a carbon sink-research and prospects," in Soil Ecology and Research Developments, T.-X. Liu, C. Steiner, W. G. Teixeira et al., Eds., pp. 1-6, Nova Science Publishers, 2007.

[108] C. Steiner, B. Glaser, W. G. Teixeira, J. Lehmann, W. E. H. Blum, and W. Zech, "Nitrogen retention and plant uptake on a highly weathered central Amazonian Ferralsol amended with compost and charcoal," Journal of Plant Nutrition and Soil Science, vol. 171, no. 6, pp. 893-899, 2008.

[109] J. Lehmann, "Biological carbon sequestration must and can be a win-win approach," Climatic Change, vol. 97, no. 3, pp. 459-463, 2009.

[110] J. Lehmann, M. C. Rillig, J. Thies, C. A. Masiello, W. C. Hockaday, and D. Crowley, "Biochar effects on soil biota-a review," Soil Biology and Biochemistry, vol. 43, no. 9, pp. 18121836, 2011.

[111] C. Steiner, W. G. Teixeira, J. Lehmann et al., "Long term effects of manure, charcoal and mineral fertilization on crop production and fertility on a highly weathered Central Amazonian upland soil," Plant and Soil, vol. 291, no. 1-2, pp. 275-290, 2007.

[112] J. Lehmann, J. P. da Silva Jr., C. Steiner, T. Nehls, W. Zech, and B. Glaser, "Nutrient availability and leaching in an archaeological Anthrosol and a Ferralsol of the Central Amazon basin: fertilizer, manure and charcoal amendments," Plant and Soil, vol. 249, no. 2, pp. 343-357, 2003.

[113] A. Downie, A. Crosky, and P. Munroe, "Physical properties of biochar," in Biochar for Environmental Management Science and Technology, J. Lehmann and S. Joseph, Eds., chapter 2, pp. 13-32, Earthscan, London, UK, 2009.

[114] A. Bagreev, T. J. Bandosz, and D. C. Locke, "Pore structure and surface chemistry of adsorbents obtained by pyrolysis of sewage sludge-derived fertilizer," Carbon, vol. 39, no. 13, pp. 1971-1979, 2001.

[115] K. Y. Chan, L. Van Zwieten, I. Meszaros, A. Downie, and S. Joseph, "Agronomic values of greenwaste biochar as a soil amendment," Australian Journal of Soil Research, vol. 45, no. 8, pp. 629-634, 2007.

[116] K. Y. Chan, L. van Zwieten, I. Meszaros, A. Downie, and S. Joseph, "Using poultry litter biochars as soil amendments," Australian Journal of Soil Research, vol. 46, no. 5, pp. 437-444, 2008.

[117] B. Glaser, J. Lehmann, and W. Zech, "Ameliorating physical and chemical properties of highly weathered soils in the tropics with charcoal-a review," Biology and Fertility of Soils, vol. 35, pp. 219-230, 2002.

[118] M. Saito, "Charcoal as a micro-habitat for VA mycorrhizal fungi, and its practical implication," Agriculture, Ecosystems and Environment, vol. 29, no. 1-4, pp. 341-344, 1990.

[119] J. Pietikäinen, O. Kiikkilä, and H. Fritze, "Charcoal as a habitat for microbes and its effect on the microbial community of the underlying humus," Oikos, vol. 89, no. 2, pp. 231-242, 2000. 
[120] C. Steiner, K. C. Das, M. Garcia, B. Förster, and W. Zech, "Charcoal and smoke extract stimulate the soil microbial community in a highly weathered xanthic Ferralsol," Pedobiologia, vol. 51, no. 5-6, pp. 359-366, 2008.

[121] L. K. Abbott and C. Gazey, "An ecological view of the formation of VA mycorrhizas," Plant and Soil, vol. 159, no. 1, pp. 69-78, 1994.

[122] O. Zackrisson, M.-C. Nilsson, and D. A. Wardle, "Key ecological function of charcoal from wildfire in the boreal forest," Oikos, vol. 77, no. 1, pp. 10-19, 1996.

[123] M. Yamato, Y. Okimori, I. F. Wibowo, S. Anshori, and M. Ogawa, "Effects of the application of charred bark of Acacia mangium on the yield of maize, cowpea and peanut, and soil chemical properties in South Sumatra, Indonesia," Soil Science and Plant Nutrition, vol. 52, no. 4, pp. 489-495, 2006.

[124] M. Ogawa, Y. Yambe, and G. Suiura, "Effect of biochar on the root nodule and VA mycorrhiza formation of soybean," in Proceedings of the International Mycological Congress, p. 578, International Mycological Association, Tokyo, Japan, 1983.

[125] M. Saito and T. Marumoto, "Inoculation with arbuscular mycorrhizal fungi: the status quo in Japan and the future prospects," Plant and Soil, vol. 244, no. 1-2, pp. 273-279, 2002.

[126] T. Ishii and K. Kadoya, "Effects of charcoal as a soil conditioner on citrus growth and vesicular-arbuscular mycorrhizal development," Journal of the Japanese Society for Horticultural Science, vol. 63, no. 3, pp. 529-535, 1994.

[127] P. F. Schweiger, A. D. Robson, N. J. Barrow, and L. K. Abbott, "Arbuscular mycorrhizal fungi from three genera induce twophase plant growth responses on a high P-fixing soil," Plant and Soil, vol. 292, no. 1-2, pp. 181-192, 2007.

[128] Z. M. Solaiman, P. Blackwell, L. K. Abbott, and P. Storer, "Direct and residual effect of biochar application on mycorrhizal root colonisation, growth and nutrition of wheat," Australian Journal of Soil Research, vol. 48, no. 6-7, pp. 546-554, 2010.

[129] M. A. Rondon, J. Lehmann, J. Ramírez, and M. Hurtado, "Biological nitrogen fixation by common beans (Phaseolus vulgaris L.) increases with bio-char additions," Biology and Fertility of Soils, vol. 43, no. 6, pp. 699-708, 2007.

[130] J. Postma, C. H. Hok-A-Hin, and J. A. van Veen, "Role of microniches in protecting introduced Rhizobium leguminosarum biovar trifolii against competition and predation in soil," Applied and Environmental Microbiology, vol. 56, no. 2, pp. 495-502, 1990.

[131] J. Lehmann and M. Rondon, "Bio-char soil management on highly weathered soils in the humid tropics," in Biological Approaches to Sustainable Soil Systems, N. Uphoff, Ed., pp. 517530, Taylor and Francis, New York, NY, USA, 2006.

[132] M. Nishio and S. Okano, "Stimulation of the growth of Alphalpha and infection of roots with indigenous vesicular-arbuscular mycorrhizal fungi by the application of biochar," Bulletin of the National Grassland Research Institute, vol. 45, pp. 61-71, 1991.

[133] D. D. Warnock, J. Lehmann, T. W. Kuyper, and M. C. Rillig, "Mycorrhizal responses to biochar in soil-concepts and mechanisms," Plant and Soil, vol. 300, no. 1-2, pp. 9-20, 2007.

[134] C. Steiner, M. Garcia, and W. Zech, "Effects of charcoal as slow release nutrient carrier on N-P-K dynamics and soil microbial population: pot experiments with ferralsol substrate," in Amazonian Dark Earths: Wim Sombroek's Vision, W. I. Woods, W. G. Teixeira, J. Lehmann, C. Steiner, A. M. G. A. WinklerPrins, and L. Rebellato, Eds., pp. 325-338, Springer, Berlin, Germany, 2009.
[135] F. B. Dazzo and W. J. Brill, "Regulation by fixed nitrogen of hostsymbiont recognition in the Rhizobium-clover symbiosis," Plant Physiology, vol. 62, no. 1, pp. 18-21, 1978.

[136] R. Lal, "Soil carbon sequestration to mitigate climate change," Geoderma, vol. 123, no. 1-2, pp. 1-22, 2004.

[137] D. A. Laird, “The charcoal vision: a win-win-win scenario for simultaneously producing bioenergy, permanently sequestering carbon, while improving soil and water quality," Agronomy Journal, vol. 100, no. 1, pp. 178-181, 2008.

[138] K. Y. Chan and Z. Xu, "Biochar: nutrient properties and their enhancement," in Biochar for Environmental Management Science and Technology, J. Lehmann and S. Joseph, Eds., chapter 5, pp. 67-84, Earthscan, London, UK, 2009.

[139] L. Beesley, E. Moreno-Jiménez, and J. L. Gomez-Eyles, "Effects of biochar and greenwaste compost amendments on mobility, bioavailability and toxicity of inorganic and organic contaminants in a multi-element polluted soil," Environmental Pollution, vol. 158, no. 6, pp. 2282-2287, 2010.

[140] C. Steiner, K. C. Das, N. Melear, and D. Lakly, "Reducing nitrogen loss during poultry litter composting using biochar," Journal of Environmental Quality, vol. 39, no. 4, pp. 1236-1242, 2010.

[141] D. N. Dempster, D. L. Jones, and D. V. Murphy, "Clay and biochar amendments decreased inorganic but not dissolved organic nitrogen leaching in soil," Soil Research, vol. 50, no. 3, pp. 216-221, 2012.

[142] Y. Ding, Y.-X. Liu, W.-X. Wu, D.-Z. Shi, M. Yang, and Z.-K. Zhong, "Evaluation of biochar effects on nitrogen retention and leaching in multi-layered soil columns," Water, Air, \& Soil Pollution, vol. 213, no. 1-4, pp. 47-55, 2010.

[143] D. N. Dempster, D. B. Gleeson, Z. M. Solaiman, D. L. Jones, and D. V. Murphy, "Decreased soil microbial biomass and nitrogen mineralisation with Eucalyptus biochar addition to a coarse textured soil," Plant and Soil, vol. 354, no. 1-2, pp. 311-324, 2012.

[144] J. M. Novak, W. J. Busscher, D. L. Laird, M. Ahmedna, D. W. Watts, and M. A. S. Niandou, "Impact of biochar amendment on fertility of a southeastern coastal plain soil," Soil Science, vol. 174, no. 2, pp. 105-112, 2009.

[145] T. H. DeLuca, M. D. MacKenzie, M. J. Gundale, and W. E. Holben, "Wildfire-produced charcoal directly influences nitrogen cycling in ponderosa pine forests," Soil Science Society of America Journal, vol. 70, no. 2, pp. 448-453, 2006.

[146] T. H. DeLuca, M. D. MacKenzie, and M. J. Gundale, "Biochar effects on soil nutrient transformation," in Biochar for Environmental Management Science and Technology, J. Lehmann and S. Joseph, Eds., chapter 14, pp. 251-280, Earthscan, London, UK, 2009.

[147] J. Major, C. Steiner, A. Downie, and J. Lehmann, "Chapter 15. Biochar effects on nutrient leaching," in Biochar for Environmental Management Science and Technology, J. Lehmann and S. Joseph, Eds., pp. 271-287, Earthscan, London, UK, 2009.

[148] J. Major, J. Lehmann, M. Rondon, and C. Goodale, "Fate of soilapplied black carbon: downward migration, leaching and soil respiration," Global Change Biology, vol. 16, no. 4, pp. 1366-1379, 2010.

[149] J. Major, M. Rondon, D. Molina, S. J. Riha, and J. Lehmann, "Maize yield and nutrition during 4 years after biochar application to a Colombian savanna oxisol," Plant and Soil, vol. 333, no. 1, pp. 117-128, 2010.

[150] O. Franco-Hernández and L. Dendooven, "Dynamics of C, N and $\mathrm{P}$ in soil amended with biosolids from a pharmaceutical 
industry producing cephalosporines or third generation antibiotics: a laboratory study," Bioresource Technology, vol. 97, no. 13, pp. 1563-1571, 2006.

[151] P. Guerra, I. Ahumada, and A. Carrasco, "Effect of biosolid incorporation to mollisol soils on $\mathrm{Cr}, \mathrm{Cu}, \mathrm{Ni}, \mathrm{Pb}$, and $\mathrm{Zn}$ fractionation, and relationship with their bioavailability," Chemosphere, vol. 68, no. 11, pp. 2021-2027, 2007.

[152] C. H. Cheng, J. Lehmann, and M. H. Engelhard, "Natural oxidation of black carbon in soils: changes in molecular form and surface charge along a climosequence," Geochimica et Cosmochimica Acta, vol. 72, no. 6, pp. 1598-1610, 2008.

[153] T. C. Flavel, Gross N fluxes and microbial population dynamics after the addition of organic amendments to coarse-textured soil [Ph.D. thesis], School of Earth and Environmental, The University of Western Australia, 2009.

[154] A. Usman, Y. Kuzyakov, and K. Stahr, "Effect of clay minerals on immobilization of heavy metals and microbial activity in a sewage sludge-contaminated soil," Journal of Soils and Sediments, vol. 5, no. 4, pp. 245-252, 2005.

[155] D. T. Strong, P. W. G. Sale, and K. R. Helyar, "The influence of the soil matrix on nitrogen mineralisation and nitrification. IV. Texture," Australian Journal of Soil Research, vol. 37, no. 2, pp. 329-344, 1999.

[156] J. Six, S. D. Frey, R. K. Thiet, and K. M. Batten, "Bacterial and fungal contributions to carbon sequestration in agroecosystems," Soil Science Society of America Journal, vol. 70, no. 2, pp. 555-569, 2006.

[157] E. M. Bach, S. G. Baer, C. K. Meyer, and J. Six, "Soil texture affects soil microbial and structural recovery during grassland restoration," Soil Biology and Biochemistry, vol. 42, no. 12, pp. 2182-2191, 2010.

[158] E. G. Gregorich, R. P. Voroney, and R. G. Kachanoski, "Turnover of carbon through the microbial biomass in soils with different texture," Soil Biology and Biochemistry, vol. 23, no. 8, pp. 799805, 1991.

[159] R. Matamala, J. D. Jastrow, R. M. Miller, and C. T. Garten, “Temporal changes in $\mathrm{C}$ and $\mathrm{N}$ stocks of restored prairie: implications for C sequestration strategies," Ecological Applications, vol. 18, no. 6, pp. 1470-1488, 2008.

[160] K. G. Eilers, C. L. Lauber, R. Knight, and N. Fierer, "Shifts in bacterial community structure associated with inputs of low molecular weight carbon compounds to soil," Soil Biology and Biochemistry, vol. 42, no. 6, pp. 896-903, 2010.

[161] L. S. England, H. Lee, and J. T. Trevors, "Bacterial survival in soil: effect of clays and protozoa," Soil Biology and Biochemistry, vol. 25, no. 5, pp. 525-531, 1993.

[162] M. Amato and J. N. Ladd, "Decomposition of ${ }^{14}$ C-labelled glucose and legume material in soils: properties influencing the accumulation of organic residue C and microbial biomass C," Soil Biology \& Biochemistry, vol. 24, no. 5, pp. 455-464, 1992.

[163] A. J. Franzluebbers, R. L. Haney, F. M. Hons, and D. A. Zuberer, "Active fractions of organic matter in soils with different texture," Soil Biology and Biochemistry, vol. 28, no. 10-11, pp. 1367-1372, 1996.

[164] R. P. Voroney, "The soil habitat," in Soil Microbiology, Ecology, and Biochemistry, A. E. Paul, Ed., pp. 25-52, Academic Press, Burlington, Mass, USA, 3rd edition, 2007.

[165] W. J. Wang, R. C. Dalal, P. W. Moody, and C. J. Smith, "Relationships of soil respiration to microbial biomass, substrate availability and clay content," Soil Biology and Biochemistry, vol. 35, no. 2, pp. 273-284, 2003.
[166] P. Lavelle and A. V. Spain, "Decomposition," in Soil Ecology, pp. 359-387, Springer, Dordrecht, The Netherlands, 2005.

[167] S. Umar, Effect of clay on plant residue decomposition [M.S. thesis], School of Earth and Environmental Sciences, University of Adelaide, Adelaide, Australia, 2010.

[168] J. M. Oades, “The retention of organic matter in soils," Biogeochemistry, vol. 5, no. 1, pp. 35-70, 1988.

[169] E. S. Krull, J. A. Baldock, and J. O. Skjemstad, "Soil texture effects on decomposition and soil carbon storage," in Net Ecosystem Exchange: Workshop Proceedings, U. F. K. Miko and R. Mueller, Eds., pp. 103-110, CRC for Greenhouse Accounting, Canberra, Australia, 2001.

[170] J. A. van Veen and P. J. Kuikman, "Soil structural aspects of decomposition of organic matter by micro-organisms," Biogeochemistry, vol. 11, no. 3, pp. 213-233, 1990.

[171] J. Hassink, "The capacity of soils to preserve organic C and N by their association with clay and silt particles," Plant and Soil, vol. 191, no. 1, pp. 77-87, 1997.

[172] J. A. Baldock and J. O. Skjemstad, "Role of the soil matrix and minerals in protecting natural organic materials against biological attack," Organic Geochemistry, vol. 31, no. 7-8, pp. 697-710, 2000.

[173] E. S. Krull, J. A. Baldock, and J. O. Skjemstad, "Importance of mechanisms and processes of the stabilisation of soil organic matter for modelling carbon turnover," Functional Plant Biology, vol. 30, no. 2, pp. 207-222, 2003.

[174] P. M. Rutherford and N. G. Juma, "Influence of soil texture on protozoa-induced mineralization of bacterial carbon and nitrogen," Canadian Journal of Soil Science, vol. 72, no. 3, pp. 183-200, 1992. 

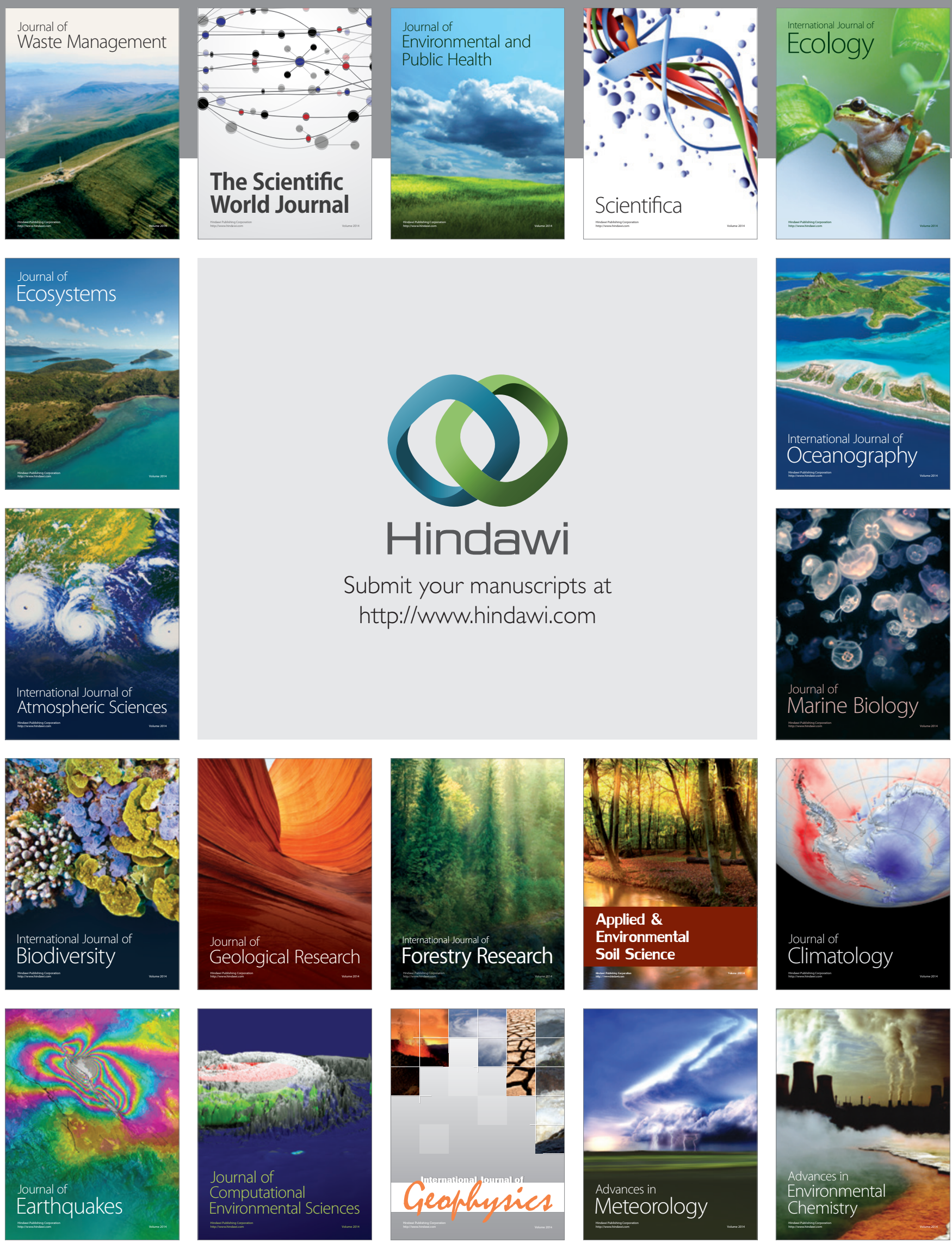